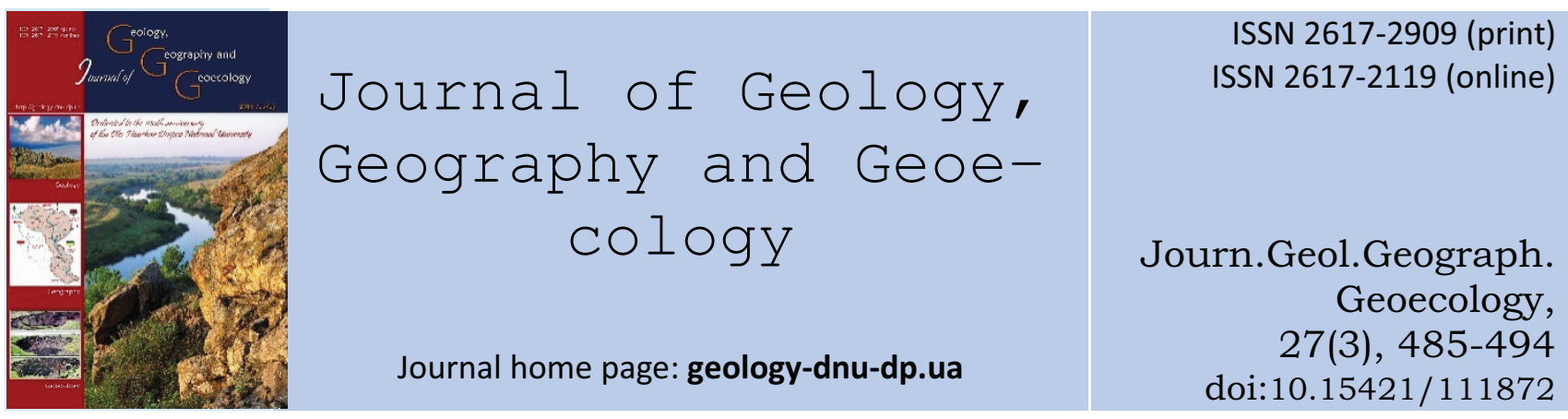

Rebati Nadia, Bouchenafa Nadia,

Oulbachir Karima, Svideniuk Mykhailo

Journ.Geol.Geograph.Geoecology, 27(3), 485-494

\title{
Remote sensing and ground based assessment of distribution of land cover parameters inthe catchment area of Wadi el K'sob M'sila (Algeria)
}

\author{
Rebati Nadia ${ }^{1}$, Bouchenafa Nadia ${ }^{1}$, Oulbachir Karima ${ }^{1}$, Svideniuk Mykhailo ${ }^{2}$ \\ ${ }^{1}$ Ibn Khaldoun University, BPP78 Zaâroura 14000, Tiaret, Algeria, e-mail: rebatin@yahoo.com \\ ${ }^{2}$ Scientific Centre for Aerospace Research of Earth, NAS Ukraine, Oles Honchar st. 55 b. Kiev, 01054, Ukraine, e- \\ mail:svideniuk_m@ukr.net
}

Received 29.09.2018;

Received in revised form 05.10.2018; Accepted 18.11.2018

Abstract. Remote sensing methodology was applied to assess two land cover parameters (elevation and soil moisture) in the first stage.Shuttle Radar Topography Mission (SRTM) digital elevation model (DEM) was used to build a map of the water catchment basins within the Wadi El K'sob area. Relative soil moisture for the territory of the Wadi El K'sob catchment area was estimated by using the Sentinel-1/Multispectral Instrument (MSI) and Landsat-8/Operational Land Imager (OLI) and Thermal Infrared Sensor (TIRS) optical multispectral data. Elevation data of the sampling points range from 398 to 1081 meters above sea level. Soil moisturevaried from 0.2 to 0.37 relative units. The effects of altitude and physico-chemical properties of soil on soil microflora communities in the catchment area of Wadi El K'sob M'sila (Algeria) were investigated in the second stage. The work presented here identified three groups of microorganisms in the soil samples collected in spring 2017 from 7 locations situated in the catchment area of Wadi El K'sob M'sila (Algeria) along with 11 physico-chemical characteristics. Statistical tests showed that actinomycetes, fungi and mesophilic bacteria were positively correlated to the altitude. The results revealed that the microflora communities was very dependent on soil physico-chemical characteristics, the main parameters were relative soil moisture, texture, $\mathrm{pH}$, electrical conductivity, organic carbon, organic matter, total nitrogen and available potassium. Generally, the parameters analyzed in this study, indicate a change in the soil microflora community according to the altitudinal and soil physico-chemical variations.

Keywords: remote sensing, land cover, catchment area, physico-chemical properties, soil microflora communities.

\section{Дистанційне зондування та наземна оцінка розподілу параметрів земельного покрову на території водозбору Ваді ель Ксоб Мсіла (Алжир)}

\author{
Ребаті Надія ${ }^{1}$, Боученатаа Надія ${ }^{1}$, Оулбачір Каріма ${ }^{1}$, Свіденюк Михайло ${ }^{2}$ \\ ${ }^{I}$ Університет Ібн Халдун, ВРР78 Задроура 14000, Tiapem, Алжир, e-mail: rebatin@yahoo.com \\ ${ }^{2}$ Науковий центр аерокосмічних дослідженьЗемлі, НАН Ккраӥни, вул..Олеся Гончара. 55 б. Київ, 01054, \\ Україна,e-mail:svideniuk_m@ukr.net
}

\begin{abstract}
Анотація. Методологія дистанційного зондування була застосована для оцінки двох параметрівгрунтового покриву (висоти i вологості грунту) на першому етапі. Цифрова модель рельєфу місцевості SRTMDEM використана для побудови карти водозбірних басейнів на території Ваді-Ель-К'соб. Відносна вологість грунту на території водозбору Ваді-ель-К'соб оцінена за допомогою приладів Sentinel-1/Multispectral (MSI) i Landsat-8, операційного землеустрою (OLI) і оптичних мультиспектральних даних тепловізійного інфрачервоного датчика (TIRS). Висотні дані точок відбору проб становлять 398 - 1081 метра над рівнем моря. Вологість грунту варіювала від 0,2 до 0,37 умовних одиниць. На другому етапі вивчався вплив висоти $i$ фізико-хімічних властивостей грунту на угрупуваннягрунтової мікрофлори у водозбірному басейні Ваді Ель-к'соб (Алжир). У даній роботі, навесні 2017 року,разом 311 фізико-хімічними показниками були визначені три групи мікроорганізмів у пробах грунту, відібраних з 7 місць, розташованих у водозбірному басейні Ваді Ель-к'соб (Алжир),. Статистичні тести показали, що актиноміцети, гриби і мезофільні бактерії позитивно корелювали з висотою. Результати показали, що спільноти мікрофлори в значній мірі залежать від фізико-хімічних характеристик грунту, основними параметрами є відносна вологість грунту, текстура, pH, електропровідність, органічний вуглець, органічна речовина, загальний азот і доступний калій. В цілому параметри, проаналізовані в даному дослідженні, свідчать про зміну спільноти грунтової мікрофлори в залежності від висотної і грунтової фізико-хімічної варіацій.
\end{abstract}


Ключові слова: дистанційне зондування, трунтово - рослинний покрив, водозбірний басейн, фізико-хімічні властивості, угрупування трунтової мікрофлори.

Introduction. Soil is the most favorable habitat for a vast diversity of microorganisms including mesophilic bacteria, fungi (Bakken, 1997, Aislabie et al., 2013) and actinomycetes (Bakken, 1997). Soil microorganisms comprise the major part of the biological diversity on earth (Aislabie et al., 2013). They play a pivotal role in soil ecosystem processes ( $\mathbf{J}$ Morin and McGrady-Steed, 2004, S Giller et al., 2004; Fierer and Jackson, 2006, Philippot et al., 2013; Schimel and Schaeffer, 2012), such as nutrient cycling, organic matter turnover (Aislabie et al. 2013), bioremediation and enhancing macroaggregate formation (Egamberdieva et al., 2010). Changes in soil microbial communities can have important effects on soil biogeochemical properties (Chapin Iii et al., 2000) which ultimately affect the functioning of the terrestrial ecosystem. Meanwhile, they are subjected to the influences of environmental factors. Environmental factors may be classified as physiographic factors, edaphic factors, climatic factors and biotic factors (Cepel, 1995; Topaloglu et al., 2016).

The effects of the soil's physico-chemical properties on soil microorganisms have been discussed in numerous studies (Guo-Mei et al. 2010; Saravanakumar et al. 2016; Dang et al. 2017). However, there is little information on the impact of altitude on soil microorganisms. Previous studies have proved that the soil microbial community is also influenced by changes in the soil's organic matter, soil pH, water content (Bååth et al. 1995; Taylor et al. 1999; Tan et al. 2005; Davidson and Janssens, 2006), the soil type (Girvan et al. 2003) and soil texture (Bekku et al. 2004; Kaštovská et al. 2005; Kaštovská et al. 2007). These factors, in turn, are influenced by the altitudinal gradient (Kidanemariam et al. 2012). Some studies have indicated that with differences in elevation there is variation in the microbial community structure and changes in microbial activity (Margesin et al. 2008; Chang et al. 2016).

The aim of this study was to build a topographic map of water catchment basins, to estimate the spatial distribution of relative soil moisture, to examine the effect of altitude on the microbial community, to reveal the relationship between physicochemical properties of the soil and microbial communities in the catchment area of Wadi El K' sob (M'sila) Algeria.

Materials and methods. Study Site.The catchment area of Wadi El K'sob is located at the northern borders of the large Hodna basin (Hadjab, 1998). It constitutes the western part of the high Plain of Constantine. The catchment area of Wadi El K'sob is located on the southern slopes of the Hodna Mountains and its water runs out towards Chott Hodna, which is an endorheic lake, i.e. deprived of a discharge outlet (Mimeche, 2014 ). The climate of the area is temperate with a mean annual temperature of $19.41{ }^{\circ} \mathrm{C}$ and annual precipitation averaging $202.26 \mathrm{~mm}$. The climate in this region is arid. The study area was mostly inhabited by plants.

\section{Effect of altitudinal gradient and soil physico- chemical properties on soil microflora com- munities in the catchment area of Wadi el K'sob M'sila (Algeria)}

In May 2017, soil samples were collected separately from seven different elevations on the catchment area of Wadi El K'sob along a south-north transect (Fig.1).

Different soil samples were extracted from the surface layer (0 to $20 \mathrm{~cm}$ depth) soils of each site and homogenized to obtain a representative sample for each station. The type of sampling used in our sector of investigation was the two way diagonal sampling. Soil samples were placed in plastic bags on ice and transported to the laboratory. Before processing, each soil sample was sieved (2 $\mathrm{mm})$ to remove the stone and root fragments and separated into two portions. One portion was stored at room temperature for chemical analysis (e.g. pH, organic matter) and the other portion at $4{ }^{\circ} \mathrm{C}$ for microbial analysis.

Laboratory Analysis. Analyses of soil physicochemical properties. Prior to determining the soil physical and chemical properties, the collected soil samples were air-dried and ground to pass through a $2 \mathrm{~mm}$ sieve. Soil texture was determined by the international Robinson pipette method. Bulk density corresponds to the ratio between the dry mass of the soil and the apparent volume. The soil moisture content (MC) was determined by oven-drying $10 \mathrm{~g}$ of soil at $105{ }^{\circ} \mathrm{C}$ for 24 hours, and the results are presented based on the soil weight loss (Hesse and Hesse, 1971). The $\mathrm{pH}$ of each soil sample was measured in distilled water at a 1: 2.5 soil: water volume ratio with a $\mathrm{pH}$ meter (HANNA). Electrical conductivity (EC) was determined according to 1:5 $(\mathrm{w} / \mathrm{v})$ soil-water suspensions at $25{ }^{\circ} \mathrm{C}$ with a conductimeter (HANNA) (Richards, 1954 ). Soil organic carbon (SOC) was determined by the ANNE method, 1945 (Aubert, 1978). The organic matter content (OMC) was obtained by multiplying SOC content with Van Bemmelen factor (1.724). Total nitrogen (TN) content was assessed via the Kjeldahl method (Qiu et al. 2010). The total calcium (calcium carbonate) was determined by the method of 
calcimeter Bernard (Baize, 1988). Active limestone was determined using the method of Drouineau-
Galet (Mathieu et al. 2003). Amounts of $\mathrm{K}+$ were analyzed flame photometrically.

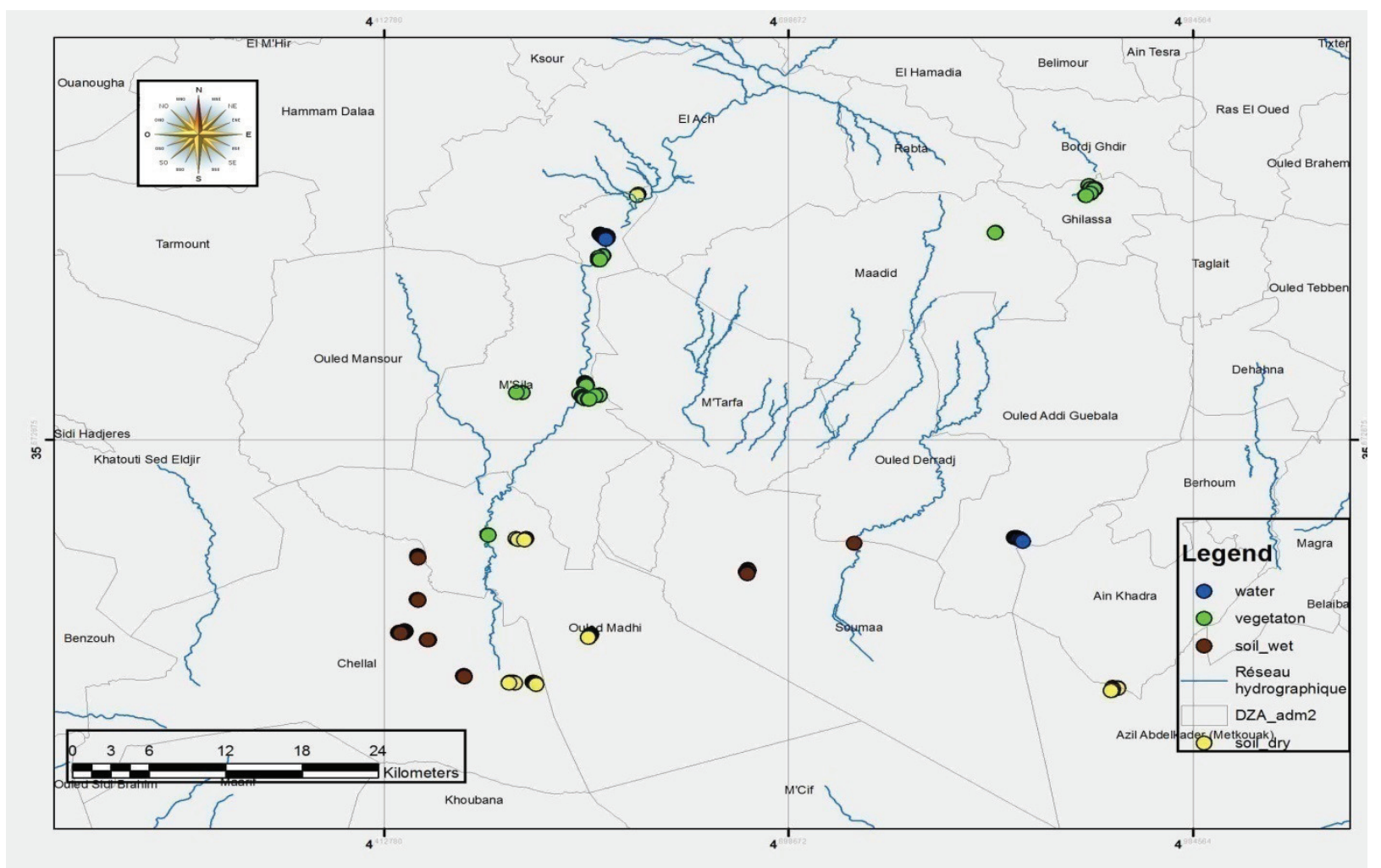

Fig. 1. The map of the catchment area of Wadi El K' sobM'sila

Laboratory Analysis. Analyses of soil physicochemical properties. Prior to determining the soil physical and chemical properties, the collected soil samples were air-dried and ground to pass through a $2 \mathrm{~mm}$ sieve. Soil texture was determined by the international Robinson pipette method. Bulk density corresponds to the ratio between the dry mass of the soil and the apparent volume. The soil moisture content (MC) was determined by oven-drying $10 \mathrm{~g}$ of soil at $105^{\circ} \mathrm{C}$ for 24 hours, and the results are presented based on the soil weight loss (Hesse and Hesse, 1971). The $\mathrm{pH}$ of each soil sample was measured in distilled water at a 1: 2.5 soil: water volume ratio with a $\mathrm{pH}$ meter (HANNA). Electrical conductivity (EC) was determined according to 1:5 (w/v) soil-water suspensions at $25{ }^{\circ} \mathrm{C}$ with a conductimeter (HANNA) (Richards, 1954 ). Soil organic carbon (SOC) was determined by the ANNE method, 1945 (Aubert, 1978). The organic matter content (OMC) was obtained by multiplying SOC content with Van Bemmelen factor (1.724). Total nitrogen (TN) content was assessed via the Kjeldahl method (Qiu et al. 2010). The total calcium (calcium carbonate) was determined by the method of calcimeter Bernard (Baize, 1988). Active limestone was determined using the method of DrouineauGalet (Mathieu et al. 2003). Amounts of $\mathrm{K}+$ were analyzed flame photometrically.
Soil Microbiological Analysis. $1 \mathrm{~g}$ of soil was mixed with $9 \mathrm{ml}$ of physiological water and shaken thoroughly. $1 \mathrm{ml}$ from the solution was then mixed in $9 \mathrm{ml}$ of physiological water to make a $10^{-2}$ dilution of this solution and in the same pattern dilutions for $10^{-3}, 10^{-4}$ etc.

Indirect numeration in solid medium. Specific methods and media were used for enumeration of the microbial counts of different groups of microbial flora: starch casein agar medium for actinomycetes, potato Dextrose Agar medium for fungi (Saravanakumar et al. 2016) and Agar Nutrient for mesophilic bacteria. Enumeration of all the microbes was done by adopting a spread plate method. $0.1 \mathrm{ml}$ of each dilution was spread uniformly on agar-medium Petri plates to determine the number of populations per gram of soil. Microorganisms were cultured at the temperature of $28 \pm 2{ }^{\circ} \mathrm{C}$. After the incubation period of 5 days for fungi, 7 days for actinomycetes and 2 days for mesophilic bacteria, the colony forming units (CFU) were counted.

Data analysis. Three replicates were used in soil physico-chemical parameters and microbiological analysis. Data presented was the average of the triplicates. One way analysis of variance (ANOVA) was used to study the effect of the altitude and physicochemical parameters of soil on soil microflora. Correlation analysis was used to demonstrate the rela- 
tionship between different parameters. All these analyses were conducted by SPSS (version 22).

Results. Shuttle Radar Topography Mission (SRTM) digital elevation model (DEM) (Fig.2a)

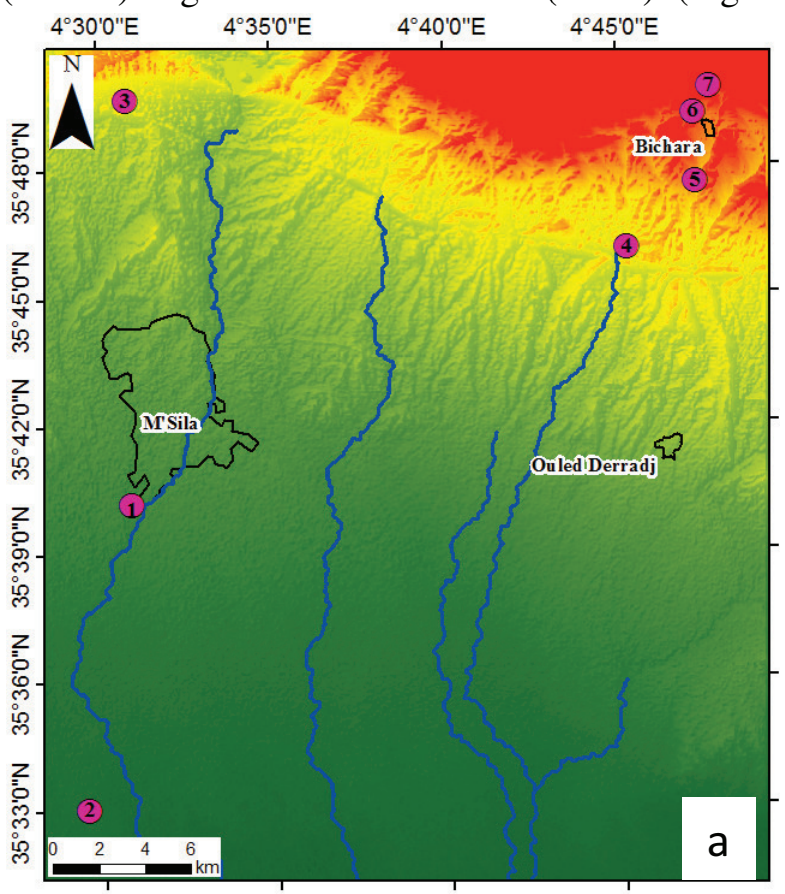

was used to build a map of the water catchment basins within (Fig.2b) the Wadi El K'sob catchment area.

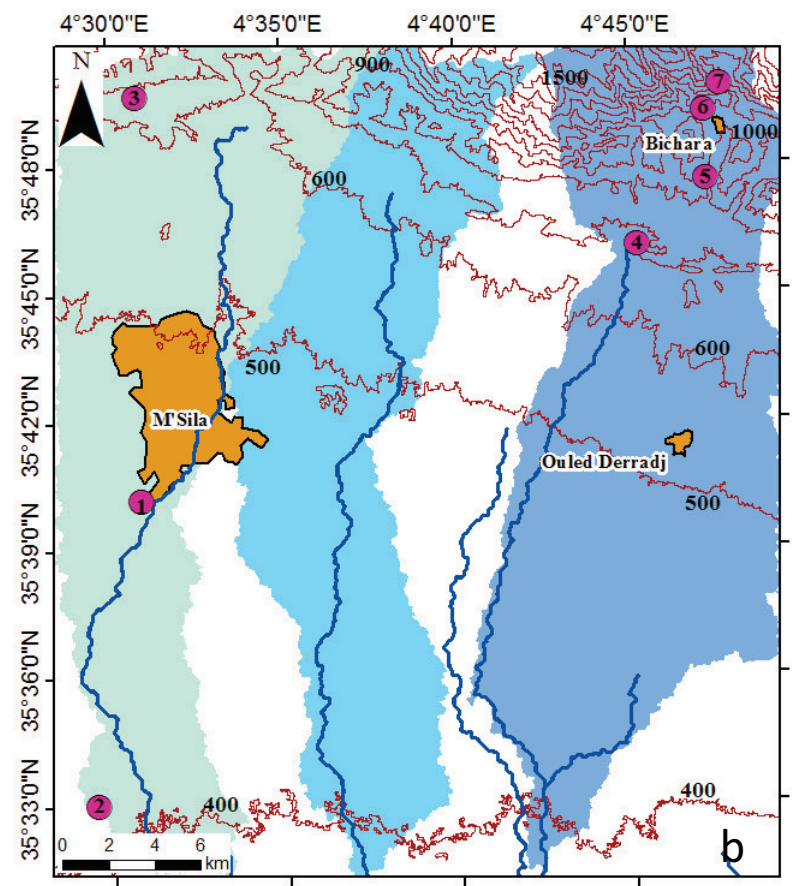

Legend

Elevation, $m$
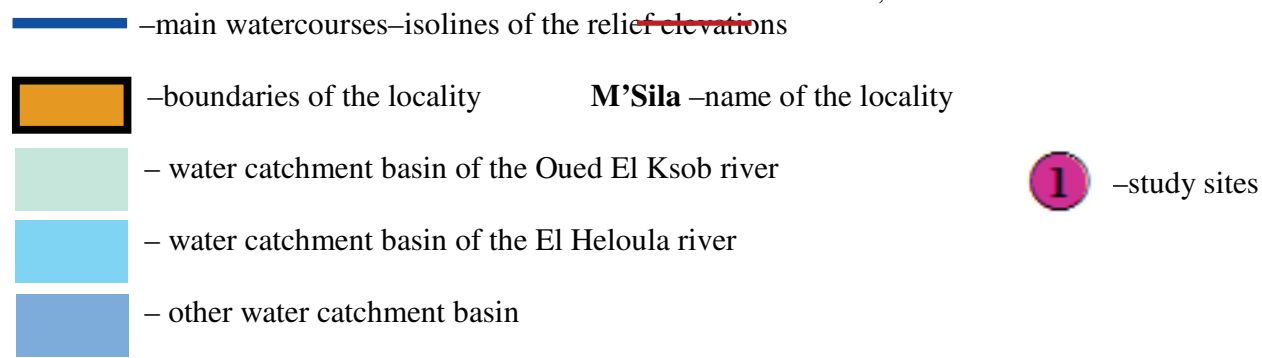

Fig. 2. The map of the basins by using the SRTM DEM: a - SRTM digital elevation model; $b$ - topographic map

Relative soil moisture for the territory of the Wadi El K'sob catchment area was estimated by using the Sentinel-1/Multispectral Instrument (MSI) and Landsat-8/Operational Land Imager (OLI) and Thermal Infrared Sensor (TIRS) optical multispectral data.

In particular, Normalized Difference Vegetation Index (NDVI) and land surface emissivity were computed to determine the land surface temperature (LST) (Stankevich et al.2016) based on Landsat-8 image of 15 May 2017. Then, the processed Sentinel-2A/MSI image of 17 May 2017 (Fig.3a) was used to compute Normalized Water Index. Finally, the products obtained of thermal and optical remote sensing were fused to determine the land cover moisture which depends on LST (Fig. 3b) (Sakhatsky et al.2007).

Data from the study sites on elevation and relative soil moisture for seven soil samples are shown in Table 1.
Elevation of the sampling points varied from 398 to 1081 meters above sea level. Soil moisture data were calculated for each sampling site using the map in Fig $3 \mathrm{~b}$ and varied from 0.2 to 0.37.

Physico-chemical parameters. The values of the physico-chemical parameters of soils are shown in Table 2.

Microbial properties. The microflora of our soil was represented by the high concentration of mesophilic bacteria followed by actinomycetes and fungi. The effects of the altitude and physicochemical properties of soils on soil microflora (mesophilic bacteria, fungi and actinomycetes) are discussed below.

Mesophilic Bacteria $\left(\mathbf{1 0}^{\mathbf{9}} \mathrm{cfu} / \mathrm{g}\right)$. The colony forming units (CFU) counts for mesophilic bacteria were significantly higher, in station $7\left(309000 \times 10^{9}\right)$ and lower in station $2\left(73 \times 10^{9}\right)$ (Fig. 4). There was a significant effect of the soil texture on mesophilic bacteria (Table 3 ). 
Rebati Nadia, Bouchenafa Nadia,
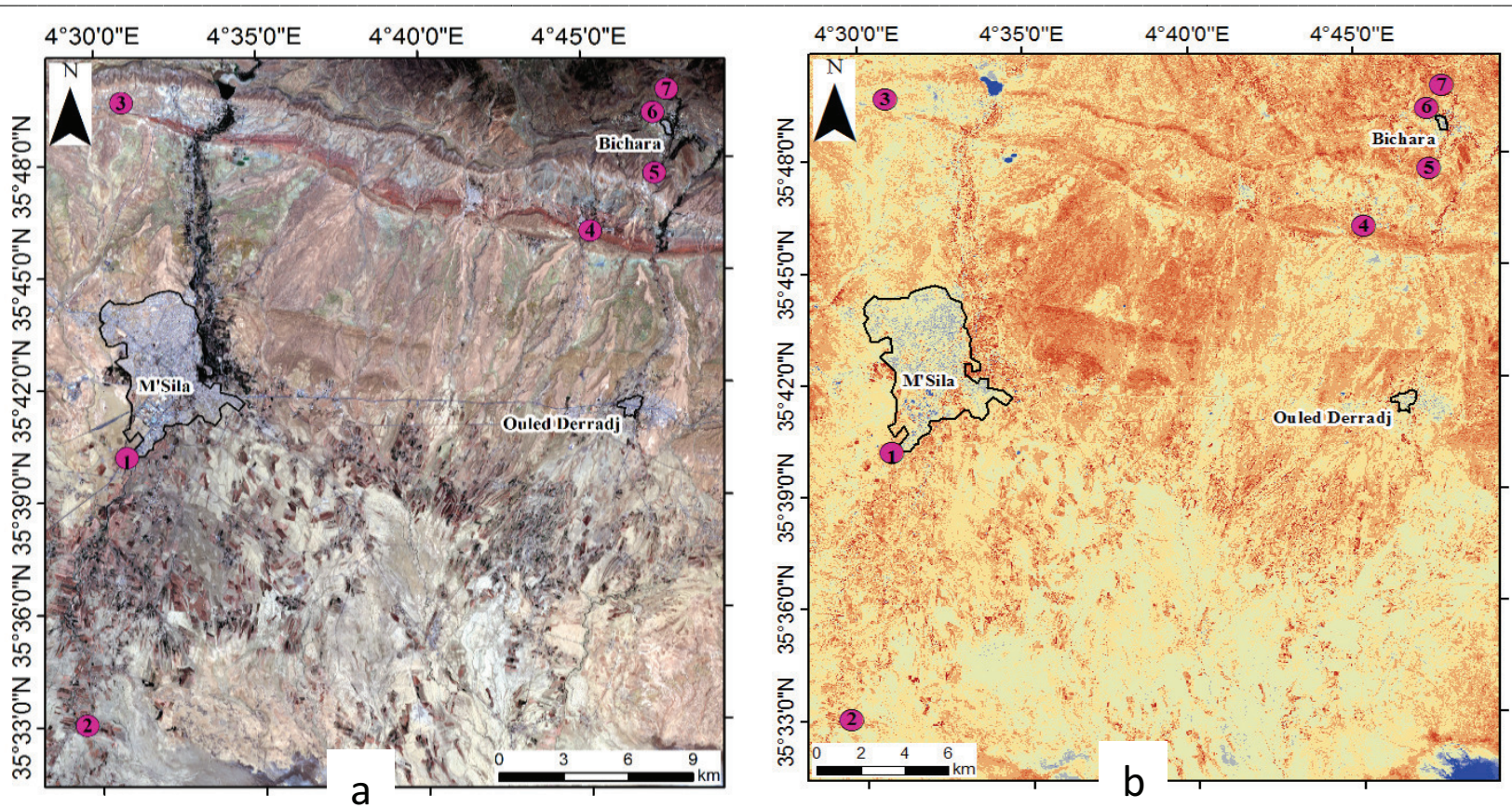

Legend

Relative soil moisture, \%

\begin{tabular}{|l|l|l|l|l|l|l|l|l|l|}
\hline & & & & & & & & & \\
\hline 0 & 20 & 23 & 26 & 30 & 34 & 40 & 45 & 50 & 60
\end{tabular}

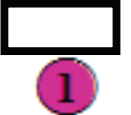

-boundaries of the locality

M'Sila -name of the locality

-study sites

Fig. 3. The map of land surface moisture relative to land surface temperature: a - optical multispectral image Sentinel-2A/MSI of 17 May 2017 (wavelengths of 0.67, 0.56 and $0.5 \mu \mathrm{m}$ in the Red, Green and Blue bands); $\mathrm{b}$ - the map of land surface moisture

Table 1. Data from study sites on elevation and soil moister

\begin{tabular}{|c|c|c|c|c|}
\hline Sampling Sites & Latitude (N) & Longitude (E) & Elevation (m) & $\begin{array}{c}\text { Relative soil mois- } \\
\text { ture }\end{array}$ \\
\hline S1 & $35^{\circ} 33^{\prime} 03.0^{\prime \prime}$ & $4^{\circ} 29^{\prime} 31^{\prime \prime}$ & 398 & 0.28 \\
S2 & $35^{\circ} 40^{\prime} 11.3^{\prime \prime}$ & $4^{\circ} 30^{\prime} 51.1^{\prime \prime}$ & 441 & 0.37 \\
S3 & $35^{\circ} 49^{\prime} 40.5^{\prime \prime}$ & $4^{\circ} 34^{\prime} 07.0^{\prime \prime}$ & 563 & 0.34 \\
S4 & $35^{\circ} 46^{\prime} 05.2^{\prime \prime}$ & $4^{\circ} 45^{\prime} 13.9^{\prime \prime}$ & 682 & 0.34 \\
S5 & $35^{\circ} 47^{\prime} 36.3^{\prime \prime}$ & $4^{\circ} 47^{\prime} 14.3^{\prime \prime}$ & 848 & 0.30 \\
S6 & $35^{\circ} 49^{\prime} 13.8^{\prime \prime}$ & $4^{\circ} 47^{\prime} 13.5^{\prime \prime}$ & 993 & 0.20 \\
S7 & $35^{\circ} 49^{\prime} 50.2^{\prime \prime}$ & $4^{\circ} 47^{\prime} 39.7^{\prime \prime}$ & 1081 & 0.29 \\
\hline
\end{tabular}

Table 2. Physical and chemical characteristics of the soils in the spring in the seven different studied sites

\begin{tabular}{|l|l|l|l|l|l|l|l|}
\hline & \multicolumn{7}{|c|}{ Spring } \\
\hline Stations & S 1 & S 2 & S 3 & S 4 & S 5 & S 6 & S 7 \\
\hline Texture & loam & loam & loam & loamy sand & silty clay & silty clay & $\begin{array}{l}\text { sandy } \\
\text { loam }\end{array}$ \\
\hline Bulk density & $1.24 \pm 0$ & $0.67 \pm 0$ & $1.51 \pm 0$ & $1.36 \pm 0$ & $1.05 \pm 0$ & $0.89 \pm 0$ & $0.92 \pm 0$ \\
\hline MC & $1.68 \pm 0$ & $1.83 \pm 0$ & $0.96 \pm 0$ & $1.99 \pm 0$ & $7.91 \pm 0$ & $0.43 \pm 0$ & $2.77 \pm 0$ \\
\hline pH & $7.67 \pm 0$ & $7.27 \pm 0$ & $7.62 \pm 0$ & $7.47 \pm 0$ & $7.8 \pm 0$ & $7.66 \pm 0$ & $8.14 \pm 0$ \\
\hline EC (uS/cm) & $945.3 \pm 20.5$ & $3650 \pm 90$ & $1842.33 \pm 109$ & $3020 \pm 20$ & $2493 \pm 620$ & $527.33 \pm 46$. & $492.33 \pm 102.5$ \\
\hline CaCO3 (\%) & $51.27 \pm 1.17$ & $36.37 \pm 1.06$ & $50.35 \pm 0.61$ & $22.8 \pm 1.23$ & $12.77 \pm 0.49$ & $41.81 \pm 0.58$ & $21.05 \pm 1.6$ \\
\hline $\begin{array}{l}\text { ActiveCaCO3 } \\
(\%)\end{array}$ & $12.5 \pm 1$ & $13.5 \pm 3.04$ & $15.5 \pm 1.32$ & $15.25 \pm 0.25$ & $13 \pm 0.58$ & $20.83 \pm 2.08$ & $10 \pm 1$ \\
\hline $\mathrm{K}(\mathrm{meq} / \mathrm{l})$ & $6.15 \pm 0$ & $12.42 \pm 0.37$ & $4.48 \pm 0.12$ & $8.72 \pm 0$ & $6.79 \pm 0,38$ & $7.92 \pm 1.82$ & $3.20 \pm 0.38$ \\
\hline $\mathrm{OC}(\%)$ & $0.86 \pm 0.005$ & $1.75 \pm 0.07$ & $1.05 \pm 0.11$ & $0.74 \pm 0.11$ & $1.21 \pm 0.24$ & $1.28 \pm 0.06$ & $0.19 \pm 0.13$ \\
\hline OM (\%) & $1.48 \pm 0.01$ & $3.01 \pm 0.13$ & $1.8 \pm 0.19$ & $0.87 \pm 0.19$ & $2.07 \pm 0.42$ & $2.21 \pm 0.11$ & $0.333 \pm 0.22$ \\
\hline $\mathrm{N}(\%)$ & $0.035 \pm 0$ & $0.15 \pm 0$ & $0.046 \pm 0$ & $0.018 \pm 0$ & $0.08 \pm 0$ & $0.19 \pm 0$ & $0.032 \pm 0$ \\
\hline $\mathrm{C} / \mathrm{N}$ & $21.5 \pm 0.14$ & $11.67 \pm 0.48$ & $21 \pm 2.44$ & $41.11 \pm 6.41$ & $15.12 \pm 3.06$ & $6.74 \pm 0.34$ & $17.81 \pm 4.08$ \\
\hline
\end{tabular}

S: Station MC: Moisture Content, EC: Electrical Conductivity, CaCO3: Calcium Carbonate, active CaCO3: Active limestone K: potassium, OC: Organic Carbone, OM: Organic Matter, N: Nitrogen, C/N: ratio Carbon on Nitrogen. 
Table 3. Output of the ANOVA analysis demonstrating the altitude and the effect of soil physico-chemical properties on soil microflora communities

\begin{tabular}{|c|c|c|c|c|c|c|}
\hline \multirow[t]{2}{*}{ Soil property } & \multicolumn{2}{|c|}{ Actinomycetes } & \multicolumn{2}{|l|}{ Fungi } & \multicolumn{2}{|c|}{ Mesophilic bacteria } \\
\hline & F-value & $\mathrm{P}$-value & F-value & $\mathrm{P}$-value & F-value & $\mathrm{P}$-value \\
\hline Altitude & 9284.37 & 0.000 & 140.68 & 0.000 & & \\
\hline Texture & 15371.4 & 0.000 & 8.19 & 0.001 & 6316.05 & 0.000 \\
\hline Bulk density & 9284.37 & 0.000 & 140.68 & 0.000 & & \\
\hline $\mathrm{MC}(\%)$ & 9284.37 & 0.000 & 140.68 & 0.000 & & \\
\hline $\mathrm{pH}$ & 9284.37 & 0.000 & 140.68 & 0.000 & & \\
\hline $\mathrm{CaCO} 3(\%)$ & & & 43.088 & 0.005 & & \\
\hline Active $\mathrm{CaCO} 3(\%)$ & 0.982 & 0.573 & 1.682 & 0.328 & 1.017 & 0.556 \\
\hline $\mathrm{OC}(\%)$ & 5968,52 & 0.000 & 90,438 & 0.000 & & \\
\hline OM $(\%)$ & 5968,52 & 0.000 & 90,438 & 0.000 & & \\
\hline $\mathrm{N}(\%)$ & 9284.37 & 0.000 & 140.68 & 0.000 & & \\
\hline $\mathrm{C} / \mathrm{N}$ & 9284,37 & 0.000 & 140,68 & 0.000 & & \\
\hline $\mathrm{K}^{+}(\mathrm{meq} / \mathrm{l})$ & 994.754 & 0.000 & & & & \\
\hline
\end{tabular}

The correlation analysis also proved a significant positive correlation between mesophilic bacteria and altitude (p b 0.01) (Table 4).

Mesophilic bacteria show negative correlation with conductivity ( $\mathrm{p} \mathrm{b}$ 0.05), organic carbon ( $\mathrm{p}$ b 0.01), organic matter ( $\mathrm{p} \mathrm{b} 0.01$ ), active limestone ( $p$ b 0.05) and available $\mathrm{K}+(\mathrm{p}$ b 0.01) while they show a positive correlation with texture $(\mathrm{p} b$ 0.01) and $\mathrm{pH}\left(\mathrm{H}_{2} \mathrm{O}\right)(\mathrm{p} \mathrm{b} 0.01)$.

Actinomycetes $\left(\mathbf{1 0}^{6} \mathbf{~ c f u} / \mathbf{g}\right)$. The actinomycete counts showed large variations at different altitudes from 0.092 to $47 \times 10^{6} \mathrm{CFU} \mathrm{g}{ }^{-1}$ dry soil (Fig. 5). Total actinomycete numbers increased with increasing altitudes. The correlation analysis also demon- strated a significant positive correlation between actinomycetes and altitude ( $\mathrm{p}$ b 0.01). ANOVA analysis also demonstrated a significant effect of altitude on actinomycetes. It was observed that populations of the actinomycetes were significantly affected by the bulk density, texture, the moisture content, $\mathrm{pH}\left(\mathrm{H}_{2} \mathrm{O}\right)$, organic carbon, organic matter, total nitrogen, $\mathrm{C} / \mathrm{N}$ ratio and available $\mathrm{K}+$. Actinomycetes showed negative correlation with conductivity ( $\mathrm{p} \mathrm{b} 0.01$ ), active limestone ( $\mathrm{p}$ b 0.01 ), organic carbon ( $\mathrm{p} \mathrm{b} 0.05)$, organic matter ( $\mathrm{p} \mathrm{b} 0.05)$ and available of $\mathrm{K}+(\mathrm{p}$ b 0.05$)$ while they showed a positive correlation with texture $(\mathrm{p} \mathrm{b} 0.01)$ and $\mathrm{pH}$ $\left(\mathrm{H}_{2} \mathrm{O}\right)(\mathrm{p} \mathrm{b} 0.01)$.

Table 4. Correlation coefficient between altitude, soil physico-chemical properties and soil microflora communities. Significance between the parameters is indicated by *p b 0.05 , **p b 0.01

\begin{tabular}{|c|c|c|c|}
\hline & Actinomycetes & Fungi & Mesophilic bacteria \\
\hline Altitude & $0.67^{* *}$ & $0.60^{* *}$ & $0.59^{* *}$ \\
\hline Texture & $0.73^{* *}$ & $0.54^{* *}$ & $0.66^{* *}$ \\
\hline Bulk density & $-0.284 \mathrm{~ns}$ & $-0.655^{* *}$ & $-0.232 \mathrm{~ns}$ \\
\hline $\mathrm{MC}(\%)$ & $0.080 \mathrm{~ns}$ & $-0.291 \mathrm{~ns}$ & $0.035 \mathrm{~ns}$ \\
\hline $\mathrm{pH}$ & $0.803^{* *}$ & $0.397 \mathrm{~ns}$ & $0.782^{* *}$ \\
\hline $\mathrm{EC}(\mathrm{uS} / \mathrm{cm})$ & $-0.478^{*}$ & $-0.476^{*}$ & $-0.480^{*}$ \\
\hline $\mathrm{CaCO}(\%)$ & $-0.411 \mathrm{~ns}$ & $-0.094 \mathrm{~ns}$ & $-0.350 \mathrm{~ns}$ \\
\hline Active CaCO3 $(\%)$ & $-0.478^{*}$ & $0.003 \mathrm{~ns}$ & $-0.516^{*}$ \\
\hline $\mathrm{OC}(\%)$ & $-0.730^{* *}$ & $-0.201 \mathrm{~ns}$ & $-0.745^{* *}$ \\
\hline $\mathrm{OM}(\%)$ & $-0.572^{* *}$ & $-0.054 \mathrm{~ns}$ & $-0.608^{* *}$ \\
\hline $\mathrm{N}(\%)$ & $-0.268 \mathrm{~ns}$ & $0.388 \mathrm{~ns}$ & $-0.325 \mathrm{~ns}$ \\
\hline $\mathrm{C} / \mathrm{N}$ & $-0.089 \mathrm{~ns}$ & $-0.515^{*}$ & $-0.053 \mathrm{~ns}$ \\
\hline $\mathrm{k}+(\mathrm{meq} / \mathrm{l})$ & $-0.555^{* *}$ & $-0.116 \mathrm{~ns}$ & $-0.575^{* *}$ \\
\hline
\end{tabular}

Fungi $\left(\mathbf{1 0}^{3} \mathbf{c f u} / \mathbf{g}\right)$. The data showed that the highest population of fungi in S7 $\left(79 \times 10^{3}\right)$, while S1exhibited the significantly lowest concentrations of fungi $\left(1.45 \times 10^{3}\right)$ (Fig. 6$)$.

Abundance of fungi was also observed to be affected significantly by altitude (Table 4 ). The fungi showed a positive correlation with altitude ( $\mathrm{p} \mathrm{b}$ 0.01). In our studies, the bulk density, texture, moisture content, $\mathrm{pH}\left(\mathrm{H}_{2} \mathrm{O}\right)$, calcium carbonate, organic carbon, organic matter, total nitrogen and $\mathrm{C} / \mathrm{N}$ ratio in the soil had a significant effect on fungi. The fungi showed a negative correlation with

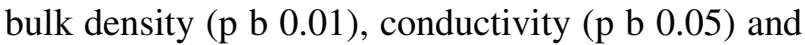
$\mathrm{C} / \mathrm{N}$ ratio $(\mathrm{p} b$ 0.01) while they showed a positive correlation with texture ( $\mathrm{p} \mathrm{b} 0.01$ ). 


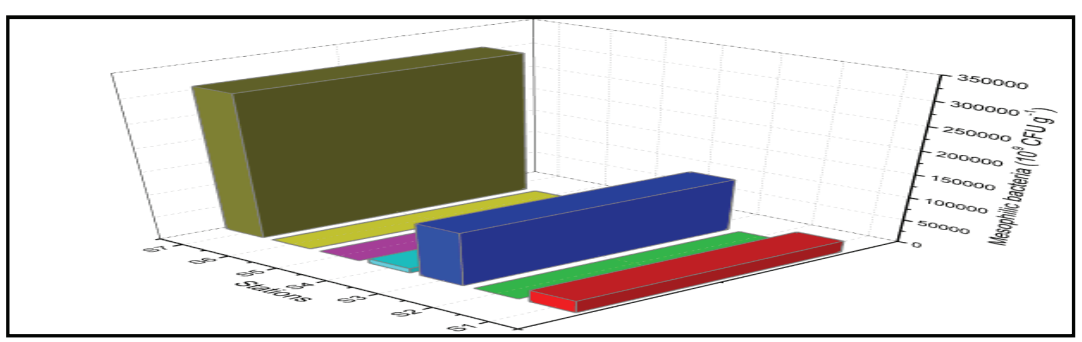

Fig. 4. Variation in the number of mesophilic bacteria in our soils

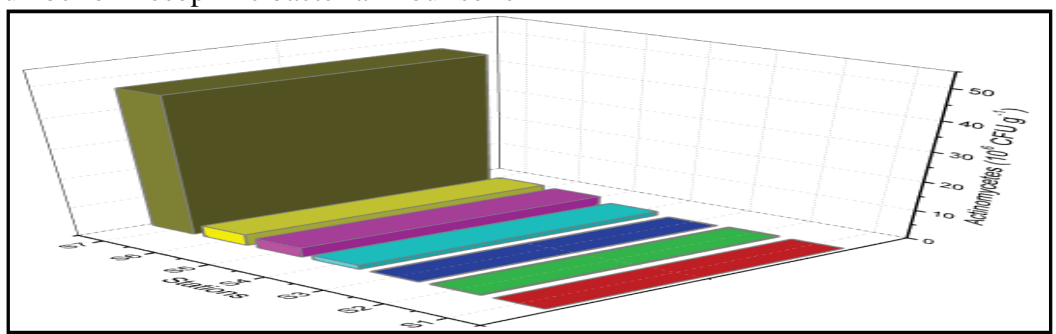

Fig. 5. Variation in the number of actinomycetes in our soils

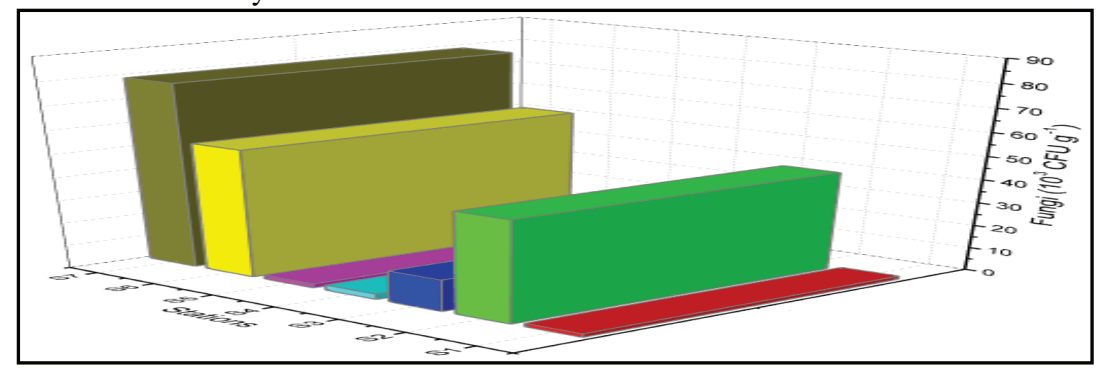

Fig. 6. Variation in the number of fungi in our soils

Discussion. Our experimental study aimed to determine the influence of altitude and soil properties on microflora communities in the catchment of Wadi El K'sob in spring. Our findings revealed that microbial communities in this environment were represented by the high concentration of mesophilic bacteria followed by actinomycetes and fungi. This is perhaps unsurprising because other environments presented the same one profile microbial communities (Baldrian et al., 2012).

Altitude is appropriate to variables that affect the ecosystem, such soil moisture, mean annual precipitation, soil organic matter, labile $\mathrm{C}$ and mineralisable $\mathrm{N}$ and microbial activities (Griffiths et al., 2009). The results showed that altitude was statistically correlated with microbial communities (Table 4). In our study, microbial, actinomycete and fungal communities were significantly influenced by altitude. The effect of altitude may due to changes in vegetation and/or to human activity at low altitudes (Faoro et al,. 2010). Some researchers (Margesin et al., 2008, Chang et al., 2016) have detected a significant rise in the populations of fungi and bacteria with increasing elevation. Other studies also generally observed a decrease in microbial biomass and activity with increasing altitude and colder climate conditions (Uchida et al., 2000, Lipson, 2006).

Thus, characterization of abiotic properties is important for providing a clearer vision of how microbial communities change. Statistical analyses showed that physico-chemical characteristics make specific contributions to soil microbial communities.

Previous studies have proved that microbial community composition appeared to vary as a function of the size of soil aggregates (Kanazawa and Filip, 1986; Sessitsch et al., 2001, Väisänen et al., 2005). We found an influence of texture and bulk density on the microbial communities of soils (Table 3). Some researchers (Bott and Kaplan, 1985, Väisänen et al., 2005) have observed that soil microbial biomass increased with decreasing grain sizes.

In agreement with our results (Table 3), many other studies have formerly described the significant effect of soil moisture on the microbial community (Barness et al., 2009). The effect of moisture content on the microbial community of soil might be due by its effect on osmotic potential, transport of nutrients and energy and cellular metabolism as well as on the competitive interactions between microbial species (Williams and Rice, 2007; Meimei et al., 2008;Barness et al., 2009).

Soil $\mathrm{pH}$ has been significantly correlated with the soil mesophilic bacteria and actinomycetes. (Lauber et al., 2008, Wang et al., 2014) confirming that bacterial communities were strongly correlated, with soil $\mathrm{pH}$. However, many studies have demonstrated that fungal biomass was not 
strongly related to soil pH (Frey et al., 1999, Lauber et al., 2008), which is also what we found (Table 4).

It had also been documented that salinity affects microbial community composition (Abdelkader Dellal, 1992, Egamberdieva et al., 2010, Zhang et al., 2013). Our results indicated that microbial communities (actinomycetes, fungiand mesophilic bacteria) were also negatively correlated with EC. Similar results were found by other researchers (Rietz and Haynes, 2003).

Our research presented a negative correlation between soil available potassium and actinomycete communities. A similar result was obtained by Cheng et al 2016.

Previous studies found that soil organic carbon played the most significant role in microbial community structure (Postma et al., 2008; Zhang et al., 2013;Cheng et al., 2016) .In our study, actinomycetes and mesophilic bacteria showed a significant correlation with organic carbon. In accordance with our result, (Frey et al., 1999) detected that the proportional fungal biomass was not strongly related to soil organic $\mathrm{C}$.

It was shown that an increase in $\mathrm{N}$ availability affects soil microbial processes (Ramirez et al., 2012;Zhang et al., 2013) . Thus, fungi appear more sensitive than bacteria to soil $\mathrm{N}$ enrichment (Frey et al., 2004). On the other hand, (Frey et al., 1999) found that fungal biomass was not strongly related to soil $\mathrm{N}$ and that is what we found (Table 4). (Postma et al., 2008) have demonstrated that among the highly significant explanatory factors of the composition of the dominant fungal population was soil $\mathrm{C} / \mathrm{N}$ ratio. This may help to explain why we found the significant effect of soil $\mathrm{C} / \mathrm{N}$ ratio on the fungal community (Table 3). It was showed also that microbial community functional structures were closely correlated with soil $\mathrm{C} / \mathrm{N}$ (Yang et al., 2013)..

Conclusions.Remote sensing approaches were applied to assess two land cover parameters (elevation and soil moisture) at the first stage of our research.

The effects of altitude and physico-chemical properties of soil on soil microflora communities in the catchment area of Wadi El K'sob M'sila (Algeria) were investigated at the second stage. Elevation data of the sampling points range from 398 to 1081 meters above sea level. Relative soil moisturevaried from 0.2 to 0.37 relative units. The results indicated that the elevation could determine the microflora community in an ecosystem. Altitude had a significant correlation with the soil microflora population of the collected samples. Also, the variations between microflora communities were clearly related to the physico-chemical characteristics of the soil, the principal parameters were texture, $\mathrm{pH}$, electrical conductivity, active limestone, organic carbon, organic matter, total nitrogen and available potassium. In conclusion, the altitude and physicochemical properties of the soil were recognized as key factors in the dynamics of the colonization of the soil by microbial populations.

Acknowledgements. We would like to thank all those who contributed to the realization of this work, particularlyMr. Dellal Abdelkader, Belouadah Zouheyr, Sarri Madani and his wife, Hendel Noui, Ben Aichata and Mme Moulay.

\section{References}

Aislabie, J., Deslippe, J. R., \& Dymond, J., 2013.Soil microbes and their contribution to soil services. Ecosystem services in New Zealand-conditions and trends. Manaaki Whenua Press, Lincoln, New Zealand, 143-161.

Aubert, G., 1978. "Méthodes d'analyses des sols," Centre national de documentation pédagogique, Centre régional de documentation pédagogique de Marseille.

Bååth, E., Frostegård, Å., Pennanen, T., \& Fritze, H., 1995. Microbial community structure and $\mathrm{pH}$ response in relation to soil organic matter quality in wood-ash fertilized, clear-cut or burned coniferous forest soils. Soil Biology and Biochemistry 27, 229-240.

Baize, D., 1988. "Guide des analyses courantes en pédologie," Institut national de la recherche agronomique.

Bakken, L. R., 1997. Culturable and nonculturable bacteria in soil. Modern Soil Microbiology, 4761.

Baldrian, P., Kolařík, M., Štursová, M., Kopecký, J., Valášková, V., Větrovský, T., Žifčáková, L., Šnajdr, J., Rídl, J., \& Vlček, Č. 2012. Active and total microbial communities in forest soil are largely different and highly stratified during decomposition. The ISME Journal 6, 248.

Barness, G., Zaragoza, S. R., Shmueli, I., \& Steinberger, Y., 2009. Vertical distribution of a soil microbial community as affected by plant ecophysiological adaptation in a desert system. Microbial Ecology57, 36-49.

Bekku, Y. S., Nakatsubo, T., Kume, A., \& Koizumi, H., 2004. Soil microbial biomass, respiration rate, and temperature dependence on a successional glacier foreland in Ny-Ålesund, Svalbard. Arctic, Antarctic, and Alpine Research, 395-399.

Bott, T., \& Kaplan, L., 1985. Bacterial biomass, metabolic state, and activity in stream sediments: relation to environmental variables and multiple assay comparisons. Applied and Environmental Microbiology50, 508-522.

Dellal, A, 1992. Activités microbiologiques en conditions salines : en cas de quelques sols salés 
de la région de Relizane (Algérie). Cahiers agricultures 1, 335-340.

Chang, E.-H., Chen, T.-H., Tian, G., \& Chiu, C.-Y., 2016. The effect of altitudinal gradient on soil microbial community activity and structure in moso bamboo plantations. Applied Soil Ecology 98, 213-220.

Chapin Iii, F. S., Zavaleta, E. S., Eviner, V. T., Naylor, R. L., Vitousek, P. M., Reynolds, H. L., Hooper, D. U., Lavorel, S., Sala, O. E., \& Hobbie, S. E., 2000. Consequences of changing biodiversity. Nature 405, 234.

Cheng, J., Jing, G., Wei, L., \& Jing, Z., 2016. Long-term grazing exclusion effects on vegetation characteristics, soil properties and bacterial communities in the semi-arid grasslands of China. Ecological Engineering 97, 170-178.

Dang, P., Yu, X., Le, H., Liu, J., Shen, Z., \& Zhao, Z., 2017. Effects of stand age and soil properties on soil bacterial and fungal community composition in Chinese pine plantations on the Loess Plateau. PloS One 12, e0186501.

Davidson, E. A., \& Janssens, I. A., 2006. Temperature sensitivity of soil carbon decomposition and feedbacks to climate change. Nature 440, 165.

Duchaufour, P., 1997). Abrégé de pédologie. Sol, végétation, environnement. 5e éd. Paris: Masson.

Egamberdieva, D., Renella, G., Wirth, S., \& Islam, R., 2010. Secondary salinity effects on soil microbial biomass. Biology and Fertility of Soils 46, 445449.

Faoro, H., Alves, A., Souza, E., Rigo, L., Cruz, L., AlJanabi, S., Monteiro, R., Baura, V., \& Pedrosa, F., 2010. Influence of soil characteristics on the diversity of bacteria in the Southern Brazilian Atlantic Forest. Applied and Environmental Microbiology76, 4744-4749.

Fierer, N., \& Jackson, R. B., 2006. The diversity and biogeography of soil bacterial communities. Proceedings of the National Academy of Sciences of the United States of America 103, 626-631.

Frey, S., Elliott, E., \& Paustian, K., 1999. Bacterial and fungal abundance and biomass in conventional and no-tillage agroecosystems along two climatic gradients. Soil Biology and Biochemistry 31, 573585.

Frey, S. D., Knorr, M., Parrent, J. L., \& Simpson, R. T., 2004. Chronic nitrogen enrichment affects the structure and function of the soil microbial community in temperate hardwood and pine forests. Forest Ecology and Management 196, 159-171.

Girvan, M. S., Bullimore, J., Pretty, J. N., Osborn, A. M., \& Ball, A. S., 2003. Soil type is the primary determinant of the composition of the total and active bacterial communities in arable soils. Applied and Environmental Microbiology 69, 1800-1809.

Griffiths, R. P., Madritch, M. D., \& Swanson, A. K., 2009. The effects of topography on forest soil characteristics in the Oregon Cascade Mountains (USA): Implications for the effects of climate change on soil properties. Forest Ecology and Management 257, 1-7.

Guo-Mei, J., Zhang, P.-D., Gang, W., Jing, C., JingCheng, H., \& Huang, Y.-P., 2010. Relationship between microbial community and soil properties during natural succession of abandoned agricultural land.Pedosphere 20, 352-360.

Hadiab, M., 1998. "Aménagementet protection des milieux naturels dans la cuvette centrale $d u$ Hodna (Algérie)," atelier national de reproduction des thèses, paris.(Ph.D. thesis)

Hesse, P. R., \& Hesse, P., 1971. A Textbook of Soil Chemical Analysis.

J Morin, P., and McGrady-Steed, J., 2004. Biodiversity and ecosystem functioning in aquatic microbial systems: a new analysis of temporal variation and species richness-predictability relations. Oikos 104, 458-466.

Kanazawa, S., \& Filip, Z., 1986. Distribution of microorganisms, total biomass, and enzyme activities in different particles of brown soil. Microbial Ecology 12, 205-215.

Kaštovská, K., Elster, J., Stibal, M., \& Šantrůčková, H., 2005. Microbial assemblages in soil microbial succession after glacial retreat in Svalbard (High Arctic). Microbial Ecology 50, 396.

Kaštovská, K., Stibal, M., Šabacká, M., Černá, B., Šantrůčková, H., \& Elster, J., 2007. Microbial community structure and ecology of subglacial sediments in two polythermal Svalbard glaciers characterized by epifluorescence microscopy and PLFA. Polar Biology 30, 277-287.

Kidanemariam, A., Gebrekidan, H., Mamo, T., \& Kibret, K., 2012. Impact of altitude and land use type on some physical and chemical properties of acidic soils in Tsegede Highlands, Northern Ethiopia. Open Journal of Soil Science 2, 223.

Lauber, C. L., Strickland, M. S., Bradford, M. A., \& Fierer, N., 2008. The influence of soil properties on the structure of bacterial and fungal communities across land-use types. Soil Biology and Biochemistry 40, 2407-2415.

Lipson, D. A., 2006. Relationships between temperature responses and bacterial community structure along seasonal and altitudinal gradients. FEMS Microbiology Ecology59, 418-427.

Margesin, R., Jud, M., Tscherko, D., \& Schinner, F., 2008. Microbial communities and activities in alpine and subalpine soils. FEMS Microbiology Ecology 67, 208-218.

Mathieu, C., Pieltain, F., \& Jeanroy, E., 2003. "Analyse chimique des sols: Méthodes choisies," Tec \& doc.

Meimei, C., Baodong, C., \& Marschner, P., 2008. Plant growth and soil microbial community structure of legumes and grasses grown in monoculture or mixture. Journal of Environmental Sciences20, 1231-1237.

Mimeche, F., 2014. Ecologie du barbeau de l'Algérie, Luciobarbus callensis (Valenciennes, 1842) (Pisces : Cyprinidae) dans le barrage d'EL K'sob 
(M'Sila). Ecole Nationale Supérieure Agronomique - EL- Harrach Alger. (Ph.D. thesis)

Philippot, L., Raaijmakers, J. M., Lemanceau, P., \&Van Der Putten, W. H., 2013. Going back to the roots: the microbial ecology of the rhizosphere. Nature Reviews Microbiology 11, 789.

Postma, J., Schilder, M. T., Bloem, J., \& van LeeuwenHaagsma, W. K., 2008. Soil suppressiveness and functional diversity of the soil microflora in organic farming systems. Soil Biology and Biochemistry 40, 2394-2406.

Qiu, L., Zhang, X., Cheng, J., \& Yin, X., 2010. Effects of black locust (Robinia pseudoacacia) on soil properties in the loessial gully region of the Loess Plateau, China. Plant and Soil 332, 207-217.

Ramirez, K. S., Craine, J. M., \& Fierer, N., 2012. Consistent effects of nitrogen amendments on soil microbial communities and processes across biomes. Global Change Biology 18, 1918-1927.

Richards, L. A., 1954 . "Diagnosis and improvement of saline and alkali soil," Washington D. C.

Rietz, D., \& Haynes, R., 2003. Effects of irrigationinduced salinity and sodicity on soil microbial activity. Soil Biology and Biochemistry 35, 845854.

S Giller, P., Hillebrand, H., Berninger, U. G., O Gessner, M., Hawkins, S., Inchausti, P., Inglis, C., Leslie, H., Malmqvist, B., \& T Monaghan, M., 2004. Biodiversity effects on ecosystem functioning: emerging issues and their experimental test in aquatic environments. Oikos 104, 423-436.

Sakhatsky O. I., StankevichS. A., 2007. Do mozhlyvostei otsiniuvannia zvolozhenosti zemnoho pokryttia za bahatospektralnymy kosmichnymy zobrazhenniamy optychnoho diapazonu na prykladi terytorii Ukrainy [On the possibilities of land cover moisture parameters determination using multispectral optical satellite images data on the by the example of Ukraine]. Reports of the National Academy of Sciences of Ukraine 11, 122-128 (in Ukrainian)

Saravanakumar, K., Anburaj, R., Gomathi, V., \& Kathiresan, K., 2016. Ecology of soil microbes in a tropical mangrove forest of south east coast of India. Biocatalysis and Agricultural Biotechnology 8, 73-85.

Schimel, J., \& Schaeffer, S. M., 2012. Microbial control over carbon cycling in soil. Frontiers in Microbiology 3, 348.

Sessitsch, A., Weilharter, A., Gerzabek, M. H., Kirchmann, H., \& Kandeler, E., 2001. Microbial population structures in soil particle size fractions of a long-term fertilizer field experiment. Applied and Environmental Microbiology 67, 4215-4224.
Stankevich S. A., Pylypchuk V. V., Lubskyi M. S., Krylova H. B., 2016. Accuracy assessment of the temperature of artificial and natural earth's surfaces determining by infrared satellite imagery. Space Science and Technology, vol.22, №4, 2028 (in Ukrainian)

Tan, X., Chang, S. X., \& Kabzems, R., 2005. Effects of soil compaction and forest floor removal on soil microbial properties and $\mathrm{N}$ transformations in a boreal forest long-term soil productivity study. Forest Ecology and Management 217, 158-170.

Taylor, L. A., Arthur, M. A., \& Yanai, R. D., 1999. Forest floor microbial biomass across a northern hardwood successional sequence. Soil Biology and Biochemistry 31, 431-439.

Topatoglu, E., AY, N., Altun, L., \& Serdar, B., 2016. Effect of altitude and aspect on various wood properties ofOriental beech (Fagus orientalis Lipsky) wood. Turkish Journal of Agriculture and Forestry 40, 397-406.

Uchida, M., Nakatsubo, T., Kasai, Y., Nakane, K., \& Horikoshi, T., 2000. Altitudinal differences in organic matter mass loss and fungal biomass in a subalpine coniferous forest, Mt. Fuji, Japan. Arctic, Antarctic, and Alpine Research, 262-269.

Väisänen, R., Roberts, M., Garland, J., Frey, S., \& Dawson, L., 2005. Physiological and molecular characterisation of microbial communities associated with different water-stable aggregate size classes. Soil Biology and Biochemistry 37, 2007-2016.

Wang, H., Yang, S.-h., Yang, J.-p., Lv, Y.-m., Zhao, X., \& Pang, J.-1., 2014. Temporal changes in soil bacterial and archaeal communities with different fertilizers in tea orchards. Journal of Zhejiang University SCIENCE B 15, 953-965.

Williams, M. A., \& Rice, C. W., 2007. Seven years of enhanced water availability influences the physiological, structural, and functional attributes of a soil microbial community. Applied Soil Ecology 35, 535-545.

Yang, Y., Wu, L., Lin, Q., Yuan, M., Xu, D., Yu, H., Hu, Y., Duan, J., Li, X., \& He, Z., 2013. Responses of the functional structure of soil microbial community to livestock grazing in the Tibetan alpine grassland. Global Change Biology 19, 637-648.

Zhang, Y., Li, Y., Wang, L., Tang, Y., Chen, J., Hu, Y., Fu, X., \& Le, Y., 2013. Soil microbiological variability under different successional stages of the Chongming Dongtan wetland and its effect on soil organic carbon storage. Ecological Engineering 52, 308-315. 